Media Informatika, Vol. 6, No. 1, Juni 2008, 1-23

ISSN: 0854-4743

\title{
RANCANG BANGUN APLIKASI SISTEM PAKAR UNTUK MENENTUKAN JENIS GANGGUAN PERKEMBANGAN PADA ANAK
}

\author{
Feri Fahrur Rohman, Ami Fauzijah \\ Jurusan Teknik Informatika, Fakultas Teknologi Industri, Universitas Islam Indonesia \\ Jalan Kaliurang, Km. 14.5, Yogyakarta, 55584, Indonesia \\ E-mail:ami@fti.uii.ac.id
}

\begin{abstract}
ABSTRAK
Sistem pakar (expert system) secara umum adalah sistem yang berusaha mengadopsi pengetahuan manusia ke komputer, agar komputer dapat menyelesaikan masalah seperti yang biasa dilakukan oleh para ahli. Atau dengan kata lain sistem pakar adalah sistem yang didesain dan diimplementasikan dengan bantuan bahasa pemrograman tertentu untuk dapat menyelesaikan masalah seperti yang dilakukan oleh para ahli. Diharapkan dengan sistem ini, orang awam dapat menyelesaikan masalah tertentu baik 'sedikit' rumit ataupun rumit sekalipun 'tanpa' bantuan para ahli dalam bidang tersebut. Sedangkan bagi para ahli, sistem ini dapat digunakan sebagai asisten yang berpengalaman. Aplikasi yang dikembangkan ini bertujuan untuk menentukan jenis gangguan perkembangan pada anak di bawah umur 10 tahun dengan hanya memperhatikan gejalagejala yang dialami. Dengan menggunakan metode Certanty Factor (CF), didapatkan nilai Kemungkinan gangguan yang dialami pasien.
\end{abstract}

Kata kunci: sistem pakar, Certanty Factor (CF)

\section{PENDAHULUAN}

\subsection{Latar Belakang}

Perkembangan komputer dewasa ini telah mengalami banyak perubahan yang sangat pesat, seiring dengan kebutuhan manusia yang semakin banyak dan kompleks. Komputer yang pada awalnya hanya digunakan oleh para akademisi dan militer, kini telah digunakan secara luas di berbagai bidang, misalnya: Bisnis, Kesehatan, Pendidikan, Psikologi, Permainan dan sebagainya. Hal ini mendorong para ahli untuk semakin mengembangkan komputer agar dapat membantu kerja manusia atau bahkan melebihi kemampuan kerja manusia.

Kecerdasan buatan atau artificial intelligence merupakan bagian dari ilmu komputer yang membuat agar mesin (komputer) dapat melakukan pekerjaan seperti dan sebaik yang dilakukan oleh manusia. Sistem cerdas (intelligent system) adalah sistem yang dibangun dengan menggunakan teknik-teknik artificial intelligence. Salah satu yang dipelajari pada kecerdasan buatan adalah teori kepastian dengan menggunakan teori Certainty Factor (CF) (Kusumadewi, 2003).

Sistem Pakar (Expert System) adalah program berbasis pengetahuan yang menyediakan solusi-solusi dengan kualitas pakar untuk problema-problema 
dalam suatu domain yang spesifik. Sistem pakar merupakan program komputer yang meniru proses pemikiran dan pengetahuan pakar dalam menyelesaikan suatu masalah tertentu. Implementasi sistem pakar banyak digunakan dalam bidang psikologi karena sistem pakar dipandang sebagai cara penyimpanan pengetahuan pakar pada bidang tertentu dalam program komputer sehingga keputusan dapat diberikan dalam melakukan penalaran secara cerdas. Irisan antara psikologi dan sistem pakar melahirkan sebuah area yang dikenal dengan nama cognition \& psycolinguistics. Umumnya pengetahuannya diambil dari seorang manusia yang pakar dalam domain tersebut dan sistem pakar itu berusaha meniru metodelogi dan kinerjanya (performance) (Kusumadewi, 2003).

Salah satu implementasi yang diterapkan sistem pakar dalam bidang psikologi, yaitu untuk sistem pakar menentukan jenis gangguan perkembangan pada anak. Anak-anak merupakan fase yang paling rentan dan sangat perlu diperhatikan satu demi satu tahapan perkembangannya. Contoh satu bentuk gangguan perkembangan adalah conduct disorder. Conduct disorder adalah satu kelainan perilaku dimana anak sulit membedakan benar salah atau baik dan buruk, sehingga anak merasa tidak bersalah walaupun sudah berbuat kesalahan. Dampaknya akan sangat buruk bagi perkembangan sosial anak tersebut. Oleh karena itu dibangun suatu sistem pakar yang dapat membantu para pakar/ psikolog anak untuk menentukan jenis gangguan perkembangan pada anak dengan menggunakan metode Certainty Factor (CF).

\subsection{Tujuan}

Tujuan dari penelitian ini adalah menghasilkan suatu sistem yang dapat digunakan untuk melakukan diagnosis gangguan pada perkembangan anak yang mampu membuat suatu keputusan yang sama, sebaik dan seperti pakar.

\subsection{Batasan Masalah}

1. Sistem pakar ini berbasis web.

2. Diasumsikan bahwa data dimasukkan oleh orang yang mengetahui perubahan tingkah laku si pasien.

3. Sistem pakar ini mendiagnosis pasien di bawah umur 10 tahun.

4. Sumber pengetahuan diperoleh dari pakar, buku-buku, dan e-book yang mendukung.

5. Metode yang digunakan dalam penyelesaian masalah ini adalah metode Certainty Factor.

\section{DASAR TEORI}

\subsection{Kecerdasan Buatan Secara Umum}

Kecerdasan buatan dapat didefinisikan sebagai mekanisme pengetahuan yang ditekankan pada kecerdasan pembentukan dan penilaian pada alat yang menjadikan mekanisme itu, serta membuat komputer berpikir secara cerdas. Kecerdasan buatan juga dapat didefinisikan sebagai salah satu bagian ilmu komputer yang membuat agar mesin (komputer) dapat melakukan pekerjaan seperti dan sebaik yang dilakukan manusia. 
Teknologi kecerdasan buatan dipelajari dalam bidang-bidang, seperti: robotika, penglihatan komputer (computer vision), jaringan saraf tiruan (artifical neural system), pengolahan bahasa alami (natural language processing), pengenalan suara (speech recognition), dan sistem pakar (expert system).

\subsection{Sistem Pakar}

Sistem pakar (expert system) secara umum adalah sistem yang berusaha mengadopsi pengetahuan manusia ke komputer, agar komputer dapat menyelesaikan masalah seperti yang biasa dilakukan oleh para ahli. Atau dengan kata lain sistem pakar adalah sistem yang didesain dan diimplementasikan dengan bantuan bahasa pemrograman tertentu untuk dapat menyelesaikan masalah seperti yang dilakukan oleh para ahli. Diharapkan dengan sistem ini, orang awam dapat menyelesaikan masalah tertentu baik 'sedikit' rumit ataupun rumit sekalipun 'tanpa' bantuan para ahli dalam bidang tersebut. Sedangkan bagi para ahli, sistem ini dapat digunakan sebagai asisten yang berpengalaman.

Sistem pakar merupakan cabang dari Artificial Intelligence (AI) yang cukup tua karena sistem ini telah mulai dikembangkan pada pertengahan tahun 1960. Sistem pakar yang muncul pertama kali adalah General-purpose problem solver (GPS) yang dikembangkan oleh Newl dan Simon. Sampai saat ini sudah banyak sistem pakar yang dibuat, seperti MYCIN, DENDRAL, XCON \& XSEL, SOPHIE, Prospector, FOLIO, DELTA, dan sebagainya (Kusumadewi, 2003).

Perbandingan sistem konvensional dengan sistem pakar sebagai berikut (Kusumadewi, 2003):

a. Sistem Konvensional

1. Informasi dan pemrosesan umumnya digabung dalam satu program sequential

2. Program tidak pernah salah (kecuali pemrogramnya yang salah)

3. Tidak menjelaskan mengapa input dibutuhkan atau bagaimana hasil diperoleh

4. Data harus lengkap

5. Perubahan pada program merepotkan

6. Sistem bekerja jika sudah lengkap.

b. Sistem Pakar

1. Knowledge base terpisah dari mekanisme pemrosesan (inference)

2. Program bisa melakukan kesalahan

3. Penjelasan (explanation) merupakan bagian dari ES

4. Data tidak harus lengkap

5. Perubahan pada rules dapat dilakukan dengan mudah

6. Sistem bekerja secara heuristik dan logik

Suatu sistem dikatakan sistem pakar apabila memiliki ciri-ciri sebagai berikut (Kusumadewi, 2003):

1. Terbatas pada domain keahlian tertentu

2. Dapat memberikan penalaran untuk data-data yang tidak pasti 
3. Dapat mengemukakan rangkaian alasan-alasan yang diberikannya dengan cara yang dapat dipahami

4. Berdasarkan pada kaidah atau rule tertentu

5. Dirancang untuk dikembangkan sacara bertahap

6. Keluarannya atau output bersifat anjuran.

Adapun banyak manfaat yang dapat diperoleh dengan mengembangkan sistem pakar, antara lain (Kusumadewi, 2003):

1. Masyarakat awam non-pakar dapat memanfaatkan keahlian di dalam bidang tertentu tanpa kesadaran langsung seorang pakar

2. Meningkatkan produktivitas kerja, yaitu bertambahnya efisiensi pekerjaan tertentu serta hasil solusi kerja

3. Penghematan waktu dalam menyelesaikan masalah yang kompleks

4. Memberikan penyederhanaan solusi untuk kasus-kasus yang kompleks dan berulang-ulang

5. Pengetahuan dari seorang pakar dapat dikombinasikan tanpa ada batas waktu

6. Memungkinkan penggabungan berbagai bidang pengetahuan dari berbagai pakar untuk dikombinasikan.

Selain banyak manfaat yang diperoleh, ada juga kelemahan pengembangan sistem pakar, yaitu (Kusumadewi, 2003):

1. Daya kerja dan produktivitas manusia menjadi berkurang karena semuanya dilakukan secara otomatis oleh sistem

2. Pengembangan perangkat lunak sistem pakar lebih sulit dibandingkan dengan perangkat lunak konvensional.

Tujuan pengembangan sistem pakar sebenarnya bukan untuk menggantikan peran manusia, tetapi untuk mensubstitusikan pengetahuan manusia ke dalam bentuk sistem, sehingga dapat digunakan oleh orang banyak.

\subsubsection{Struktur Sistem Pakar}

Sistem pakar disusun oleh dua bagian utama, yaitu lingkungan pengembangan (development environment) dan lingkungan konsultasi (consultation environment) (Turban, 1995). Lingkungan pengembangan sistem pakar digunakan untuk memasukkan pengetahuan pakar ke dalam lingkungan sistem pakar, sedangkan lingkungan konsultasi digunakan oleh pengguna yang bukan pakar guna memperoleh pengetahuan pakar. Komponen-komponen sistem pakar dalam dua bagian tersebut dapat dilihat pada Gambar 1.

Komponen-komponen yang terdapat dalam sistem pakar adalah seperti yang terdapat pada Gambar 1, yaitu User Interface (antarmuka pengguna), basis pengetahuan, akuisisi pengetahuan, mesin inference, workplace, fasilitas penjelasan, perbaikan pengetahuan. 


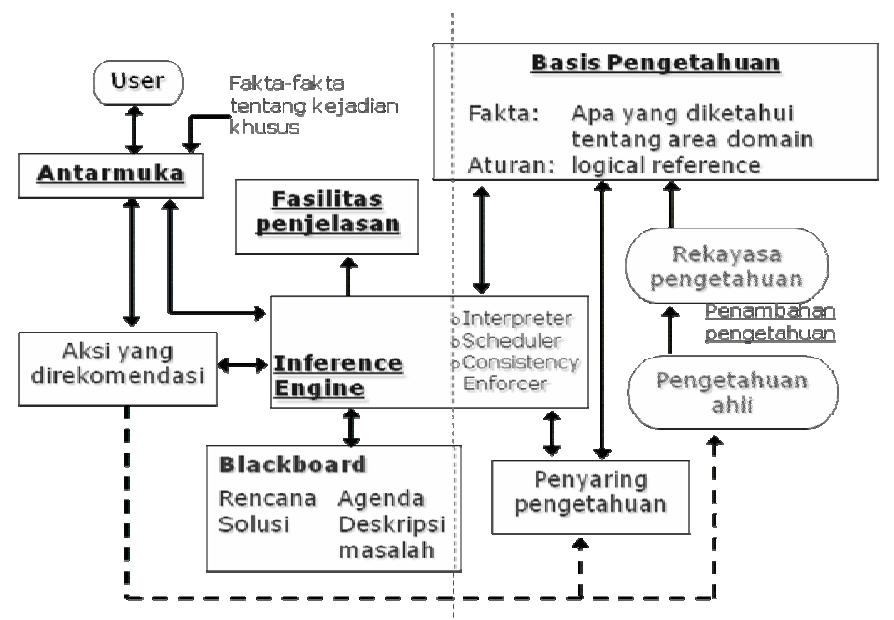

Gambar 1. Arsitektur sistem pakar

Seorang pakar mempunyai pengetahuan tentang masalah yang khusus. Dalam hal ini disebut domain knowledge. Penggunaan kata "domain" untuk memberikan penekanan pengetahuan pada problem yang spesifik. Pakar menyimpan domain knowledge pada Long Term Memory (LTM) atau ingatan jangka panjangnya.

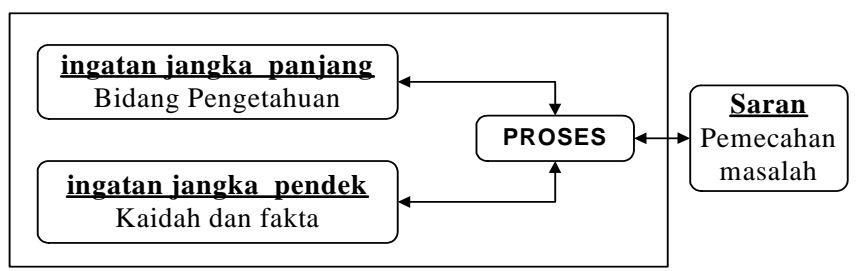

Gambar 2. Pemecahan masalah pada pakar

Ketika pakar akan memberikan nasihat atau solusi kepada seseorang, pakar terlebih dahulu menentukan fakta-fakta dan menyimpannya ke dalam Short Term Memory (STM) atau ingatan jangka pendek. Kemudian pakar memberikan solusi tentang masalah tersebut dengan mengkombinasikan fakta-fakta pada STM dengan pengetahuan LTM. Dengan menggunakan proses ini pakar mendapatkan informasi baru dan sampai pada kesimpulan masalah. Gambar 2 menunjukan berkas diagram pemecahan masalah dengan pendekatan yang digunakan pakar.

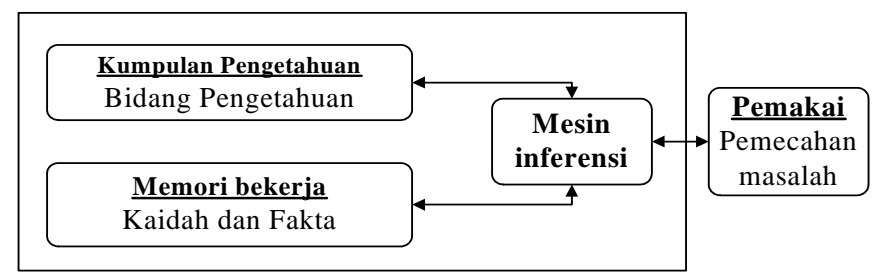

Gambar 3. Struktur pemecahan masalah pada sistem pakar 
Sistem pakar dapat memecahkan masalah menggunakan proses yang sama dengan metode yang digunakan oleh pakar, struktur yang digunakan ditunjukan pada Gambar 3.

\subsubsection{Komponen Sistem pakar}

Sebuah program yang difungsikan untuk menirukan seorang pakar manusia harus bisa melakukan hal-hal yang dapat dikerjakan seorang pakar. Untuk membangun sistem seperti itu maka komponen-komponen dasar yang harus dimilikinya paling sedikit adalah sebagai berikut:

1. Antar muka pemakai (User Interface)

2. Basis pengetahuan (Knowledge Base)

3. Mesin inferensi

Sedangkan untuk menjadikan sistem pakar menjadi lebih menyerupai seorang pakar yang berinteraksi dengan pemakai, maka dapat dilengkapi dengan fasilitas berikut:

1. Fasilitas penjelasan (Explanation)

2. Fasilitas Akuisisi pengetahuan (Knowledge acquisition facility)

3. Fasilitas swa-pelatihan (self-training)

\subsubsection{Metode Inferensi}

Komponen ini mengandung mekanisme pola pikir dan penalaran yang digunakan oleh pakar dalam menyelesaikan suatu masalah. Metode inferensi adalah program komputer yang memberikan metedologi untuk penalaran tentang informasi yang ada dalam basis pengetahuan dan dalam workplace, dan untuk memformulasikan kesimpulan (Turban, 1995).

Kebanyakan sistem pakar berbasis aturan menggunakan strategi inferensi yang dinamakan modus ponen. Berdasarkan strategi ini, jika terdapat aturan "IF A THEN B", dan jika diketahui bahwa A benar, maka dapat disimpulkan bahwa B juga benar. Strategi inferensi modus ponen dinyatakan dalam bentuk:

$[\mathrm{A}$ And $(\mathrm{A} \rightarrow \mathrm{B})] \rightarrow \mathrm{B}$

dengan $\mathrm{A}$ dan $\mathrm{A} \rightarrow \mathrm{B}$ adalah proposisi-proposisi dalam basis pengetahuan.

Terdapat dua pendekatan untuk mengontrol inferensi dalam sistem pakar berbasis aturan, yaitu pelacakan ke belakang (Backward chaining) dan pelacakan ke depan (forward chaining).

\section{a. Pelacakan ke belakang (Backward Chaining)}

Pelacakan ke belakang adalah pendekatan yang dimotori oleh tujuan (goaldriven). Dalam pendekatan ini pelacakan dimulai dari tujuan, selanjutnya dicari aturan yang memiliki tujuan tersebut untuk kesimpulannya. Selanjutnya proses pelacakan menggunakan premis untuk aturan tersebut sebagai tujuan baru dan mencari aturan lain dengan tujuan baru sebagai kesimpulannya. Proses berlanjut sampai semua kemungkinan ditemukan (Kusumadewi, 2003). Gambar 4 menunjukan proses backward chaining.

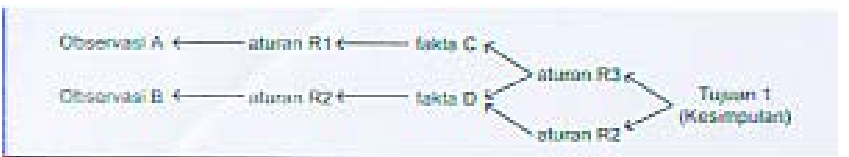

Gambar 4. Proses backward chaining 


\section{b. Pelacakan ke depan (forward chaining)}

Pelacakan kedepan adalah pendekatan yang dimotori data (data-driven). Dalam pendekatan ini pelacakan dimulai dari informasi masukan, dan selanjutnya mencoba menggambarkan kesimpulan. Pelacakan ke depan, mencari fakta yang sesuai dengan bagian IF dari aturan IF-THEN. Gambar 5 menunjukkan proses forward chaining.

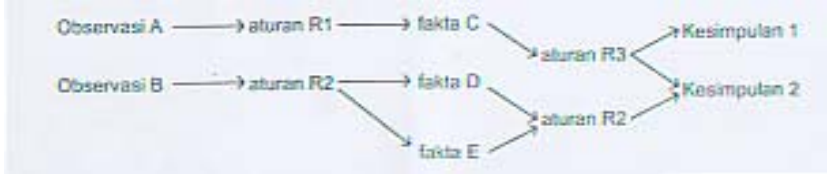

Gambar 5. Proses forward chaining

\subsubsection{Representasi Pengetahuan}

Setelah menerima bidang kepakaran yang telah diaplikasikan pada sistem pakar, kemudian mengumpulkan pengetahuan yang sesuai dengan domain keahlian tersebut. Pengetahuan yang dikumpulkan tersebut tidak bisa diaplikasikan begitu saja dalam sistem. Pengetahuan harus direpresentasikan dalam format tertentu dan dihimpun dalam suatu basis pengetahuan.

Pengetahuan yang dilakukan pada sistem pakar merupakan serangkaian informasi pada domain tertentu. Kedua hal tersebut menurut ekspresi klasik oleh Wirth ditulis sebagai berikut:

Algoritma + Struktur Data $=$ Program

Pengetahuan + Inferensi $=$ Sistem Pakar

Noise merupakan suatu item yang tidak mempunyai maksud (interest). Noise merupakan data yang masih kabur atau tidak jelas. Data adalah item yang mempunyai makna potensial. Data diolah menjadi pengetahuan. Meta knowledge adalah pengetahuan tentang pengetahuan dan keahlian.

Karakteristik pengetahuan yang diperoleh tergantung pada sifat masalah yang akan diselesaikan, tipe dan tingkat pengetahuan seorang pakar. Pengetahuan harus diekstraksikan dan dikodekan dalam suatu bentuk tertentu untuk memecahkan masalah. Ketika pengetahuan dalam suatu bidang kepakaran tersedia, maka dipilih representasi pengetahuan yang tepat. Pengetahuan dapat digolongkan menjadi dua kategori, yaitu: pengetahuan deklaratif dan pengetahuan prosedural.

Pengetahuan deklaratif mengacu pada fakta, sedangkan pengetahuan prosedural mengacu pada serangkaian tindakan dan konsekuensinya. Pengetahuan deklaratif juga terlibat dalam pemecahan masalah, sedangkan pengetahuan prosedural diasosiasikan dengan bagaimana menerapkan strategi atau prosedur penggunaan pengetahuan yang tepat untuk memecahkan masalah.

Pengetahuan deklaratif menggunakan basis logika dan pendekatan relasi. Representasi logika menggunakan logika proporsional dan logika predikat. Model relasi menggunakan jaringan semantik, graph dan pohon keputusan (decision tree). Pengetahuan prosedural menggunakan algoritma sebagai prosedural pemecahan masalah. 


\subsubsection{Ketidakpastian dengan Teori Certainty Factor (Teori Kepastian)}

Dalam menghadapi suatu permasalahan sering ditemukan jawaban yang tidak memiliki kepastian penuh. Ketidakpastian ini dapat berupa probabilitas atau kebolehjadian yang tergantung dari hasil suatu kejadian. Hasil yang tidak pasti disebabkan oleh dua faktor, yaitu aturan yang tidak pasti dan jawaban pengguna yang tidak pasti atas suatu pertanyaan yang diajukan oleh sistem. Hal ini sangat mudah dilihat pada sistem diagnosis penyakit, dimana pakar tidak dapat mendefinisikan hubungan antara gejala dengan penyebabnya secara pasti, dan pasien tidak dapat merasakan suatu gejala dengan pasti pula. Pada akhirnya akan ditemukan banyak kemungkinan diagnosis.

Sistem pakar harus mampu bekerja dalam ketidakpastian. Sejumlah teori telah ditemukan untuk menyelesaikan ketidakpastian, termasuk diantaranya probabilitas klasik, probabilitas bayes, teori hartley berdasarkan himpunan klasik, teori shannon berdasakan pada probabilitas, teori Depmster-Shafer, teori fuzzy Zadeh, dan faktor kepastian (certanity factor).

Faktor kepastian (Certanity Factor) diperkenalkan oleh Shortliffe Buchanan dalam pembuatan MYCIN (Kusumadewi, 2003). Certanity Factor (CF) merupakan nilai parameter klinis yang diberikan MYCIN untuk menunjukkan besarnya kepercayaan. Certanity Factor (CF) menunjukkan ukuran kepastian terhadap suatu fakta atau aturan.

Certanity factor didefinisikan sebagai berikut:

$\mathrm{CF}[\mathrm{h}, \mathrm{e}]=\mathrm{MB}[\mathrm{h}, \mathrm{e}]-\mathrm{MD}[\mathrm{h}, \mathrm{e}]$

dengan:

$\mathrm{CF}[\mathrm{h}, \mathrm{e}]=$ Faktor kepastian

$\mathrm{MB}[\mathrm{h}, \mathrm{e}]=$ Ukuran kepercayaan terhadap hipotesis $\mathrm{h}$, jika diberikan evidence $\mathrm{e}$ (antara 0 dan 1 )

$\mathrm{MD}[\mathrm{h}, \mathrm{e}]=$ Ukuran ketidakpercayaan terhadap hipotesis $\mathrm{h}$, jika diberikan evidence $\mathrm{e}$ (antara 0 dan 1)

Gambar 7 menunjukkan kombinasi aturan ketidakpastian:

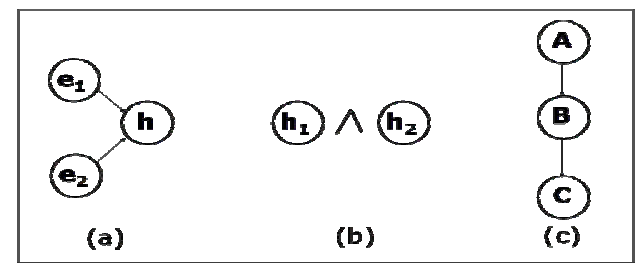

Gambar 7. Kombinasi aturan ketidakpastian

Ada 3 hal yang mungkin terjadi pada Certanity Factor (CF):

1. Beberapa evidence dikombinasikan untuk menentukan CF dari suatu hipostesis (Gambar 7a). Jika e $e_{1}$ dan $\mathrm{e}_{2}$ adalah observasi, maka:

$$
\begin{aligned}
& M B\left[h, e_{1} \wedge e_{2}\right]=\left\{\begin{array}{cc}
M B\left[h, e_{1} \wedge e_{2}\right]=1 \\
M B\left[h e_{1}\right]+M B\left[h, e_{2}\right] .\left(1-M B\left[h, e_{1}\right]\right) & \text { lainnya }
\end{array}\right. \\
& M D\left[h, e_{1} \wedge e_{2}\right]=\left\{\begin{array}{cc}
0 B\left[h, e_{1} \wedge e_{2}\right]=1 \\
M D\left[h, e_{1}\right]+M D\left[h, e_{2}\right] .\left(1-M D\left[h, e_{1}\right]\right) & \text { lainnya }
\end{array}\right.
\end{aligned}
$$


2. CF dihitung dari kombinasi beberapa hipotesis (Gambar $7 b$ ), jika $h_{1}$ dan $h_{2}$ adalah hipotesis, maka:

$$
\begin{aligned}
& \mathrm{MB}\left[\mathrm{h}_{1} \wedge \mathrm{h}_{2}, \mathrm{e}\right]=\min \left(\mathrm{MB}\left[\mathrm{h}_{1}, \mathrm{e}\right], \mathrm{MB}\left[\mathrm{h}_{2}, \mathrm{e}\right]\right) \\
& \mathrm{MB}\left[\mathrm{h}_{1} \vee \mathrm{h}_{2}, \mathrm{e}\right]=\max \left(\mathrm{MB}\left[\mathrm{h}_{1}, \mathrm{e}\right], \mathrm{MB}\left[\mathrm{h}_{2}, \mathrm{e}\right]\right) \\
& \operatorname{MD}\left[h_{1} \wedge h_{2}, \mathrm{e}\right]=\min \left(M D\left[h_{1}, \mathrm{e}\right], M D\left[h_{2}, \mathrm{e}\right]\right) \\
& \mathrm{MD}\left[\mathrm{h}_{1} \vee \mathrm{h}_{2}, \mathrm{e}\right]=\max \left(\mathrm{MD}\left[\mathrm{h}_{1}, \mathrm{e}\right], \mathrm{MD}\left[\mathrm{h}_{2}, \mathrm{e}\right]\right) \\
& C F\left[h_{1} \wedge h_{2}, e\right]=M B\left[h_{1} \wedge h_{2}, e\right]-M D\left[h_{1} \wedge h_{2}, e\right] \\
& \mathrm{CF}\left[h_{1} \vee h_{2}, \mathrm{e}\right]=M B\left[h_{1} \vee h_{2}, \mathrm{e}\right]-M D\left[h_{1} \vee h_{2}, \mathrm{e}\right]
\end{aligned}
$$

3. Beberapa aturan saling bergandengan, ketidakpastian dari suatu aturan menjadi input untuk aturan yang lainnya (Gambar 7c), maka:

$\mathrm{MB}[\mathrm{h}, \mathrm{s}]=\mathrm{MB}^{\prime}[\mathrm{h}, \mathrm{s}]^{*} \max (0, \mathrm{CF}[\mathrm{s}, \mathrm{e}])$

dengan $\mathrm{MB}^{\prime}[\mathrm{h}, \mathrm{s}]$ adalah ukuran kepercayaan $\mathrm{h}$ berdasarkan keyakinan penuh terhadap validitas $\mathrm{s}$.

\subsection{Gangguan Perkembangan pada Anak}

Manusia dalam hidupnya selalu mengalami perkembangan. Dari mulai dilahirkan sebagai seorang bayi, berkembang menjadi anak-anak, remaja, dewasa, tua dan akhirnya meninggal dunia. Dalam perjalanannya tersebut tidak sedikit yang mengalami berbagai gangguan dan permasalahan yang kemudian disebut sebagai hambatan atau gangguan perkembangan. Sebuah perkembangan yang terjadi pada diri manusia akan mempengaruhi perkembangan selanjutnya, karenannya perlu ada perhatian khusus dalam masalah ini sebagai tindakan preventif, sehingga harapannya perkembangan yang akan berlangsung selanjutnya dalam kondisi yang positif. Anak-anak merupakan fase yang paling rentan dan sangat perlu diperhatikan satu demi satu tahapan perkembangan yang dialaminya.

\subsubsection{Jenis Gangguan perkembangan anak}

\section{a. Keterbelakangan mental (Mental Retardetion)}

- Definisi Keterbelakangan mental

Keterbelakangan Mental (Retardasi Mental, RM) adalah suatu keadaan yang ditandai dengan fungsi kecerdasan umum yang berada dibawah rata-rata disertai dengan berkurangnya kemampuan untuk menyesuaikan diri (berprililaku adaptif), yang mulai timbul sebelum usia 10 tahun.

- Penyebab Keterbelakangan Mental

Tingkat kecerdasan ditentukan oleh faktor keturunan dan lingkungan. Pada sebagian besar kasus RM, penyebabnya tidak diketahui; hanya $25 \%$ kasus yang memiliki penyebab yang spesifik (Maharani,2007).

Secara kasar, penyebab RM dibagi menjadi beberapa kelompok:

1. Trauma (sebelum dan sesudah lahir)

- Perdarahan intrakranial sebelum atau sesudah lahir

- Hipoksia (kekurangan oksigen), sebelum, selama atau sesudah lahir

- Cedera kepala yang berat 
2. Infeksi (bawaan dan sesudah lahir)

- Rubella kongenitalis

- Meningitis

- Infeksi sitomegalovirus bawaan

- Ensefalitis

- Toksoplasmosis kongenitalis

- Infeksi HIV

3. Kelainan kromosom

- Kesalahan pada jumlah kromosom (Sindroma Down)

- Defek pada kromosom (sindroma X yang rapuh, sindroma Angelman, sindroma Prader-Willi)

- Translokasi kromosom dan sindroma cri du chat

4. Kelainan genetik dan kelainan metabolik yang diturunkan

- Galaktosemia

- Penyakit Tay-Sachs

- Fenilketonuria

- Sindroma Hunter

- Sindroma Hurler

- Sindroma Sanfilippo

- Leukodistrofi metakromatik

- Adrenoleukodistrofi

- Sindroma Lesch-Nyhan

- Sindroma Rett

- Sklerosis tuberose

5. Metabolik

- Sindroma Reye

- Dehidrasi hipernatremik

- Hipotiroid kongenital

- Hipoglikemia

6. Keracunan

- Pemakaian alkohol, amfetamin dan obat lain pada ibu hamil

- Keracunan metilmerkuri

- Keracunan timah hitam

7. Gizi

- Kwashiorkor

- Marasmus

- Malnutrisi

8. Lingkungan

- Kemiskinan

- Status ekonomi rendah

- Sindroma deprivasi. 


\section{- Gejala Keterbelakangan Mental}

Table 1 menunjukkan tingkatan Retardasi Mental berdasarkan IQ pada usia prasekolah dan usia sekolah.

Tabel 1. Tingkatan Retardasi Mental

\begin{tabular}{|c|c|c|c|}
\hline Tingkat & $I Q$ & Usia Prasekolah dari lahir-5 tahun & Usia Sekolah dari 6-12 tahun \\
\hline Ringan & $52-68$ & $\begin{array}{l}\text { - Bisa membangun kemampuan } \\
\text { sosial \& komunikasi } \\
\text { - Koordinasi otot sedikit terganggu } \\
\text { - Sering tidak terdiagnosis }\end{array}$ & $\begin{array}{l}\text { - Bisa mempelajari pelajaran } \\
\text { kelas } 6 \text { pada akhir usia } \\
\text { belasan tahun } \\
\text { - Bisa dibimbing ke arah } \\
\text { pergaulan sosial } \\
\text { - Bisa dididik }\end{array}$ \\
\hline Moderat & $36-51$ & $\begin{array}{l}\text { - } \text { Bisa berbicara \& belajar } \\
\text { berkomunikasi } \\
\text { - Kesadaran sosial kurang } \\
\text { - Koordinasi otot cukup }\end{array}$ & $\begin{array}{l}\text { - Bisa mempelajari beberapa } \\
\text { kemampuan sosial \& } \\
\text { pekerjaan } \\
\text { - Bisa belajar bepergian sendiri } \\
\text { di tempat-tempat yang } \\
\text { dikenalnya dengan baik } \\
\end{array}$ \\
\hline Berat & $20-35$ & $\begin{array}{l}\text { - Bisa mengucapkan beberapa kata } \\
\text { - Mampu mempelajari kemampuan } \\
\text { untuk menolong diri sendiri } \\
\text { - Tidak memiliki kemampuan } \\
\text { ekspresif atau hanya sedikit } \\
\text { - Koordinasi otot jelek }\end{array}$ & $\begin{array}{l}\text { - Bisa berbicara atau belajar } \\
\text { berkomunikasi } \\
\text { - Bisa mempelajari kebiasaan } \\
\text { hidup sehat yang sederhana }\end{array}$ \\
\hline $\begin{array}{l}\text { Sangat } \\
\text { berat }\end{array}$ & $\begin{array}{l}19 \text { atau } \\
\text { kurang }\end{array}$ & $\begin{array}{l}\text { - Sangat terbelakang } \\
\text { - Koordinasi ototnya sedikit sekali } \\
\text { - Mungkin memerlukan perawatan } \\
\text { khusus }\end{array}$ & $\begin{array}{l}\text { - Memiliki beberapa koordinasi } \\
\text { otot } \\
\text { - Kemungkinan tidak dapat } \\
\text { berjalan atau berbicara }\end{array}$ \\
\hline
\end{tabular}

\section{- Diagnosa Keterbelakangan mental}

Tingkat kecerdasan yang berada dibawah rata-rata bisa dikenali dan diukur melalui tes kecerdasan standar (tes $I Q$ ), yang menunjukkan hasil kurang dari 2 SD (standar deviasi) dibawah rata-rata (biasanya dengan angka kurang dari 70, dari rata-rata 100).

\section{- Pengobatan Keterbelakangan mental}

Tujuan pengobatan yang utama adalah mengembangkan potensi anak semaksimal mungkin. Sedini mungkin diberikan pendidikan dan pelatihan khusus, yang meliputi pendidikan dan pelatihan kemampuan sosial untuk membantu anak berfungsi senormal mungkin. Pendekatan perilaku sangat penting dalam memahami dan bekerja sama dengan anak RM (Maharani, 2007).

\section{- Pencegahan Keterbelakangan mental}

Konsultasi genetik akan memberikan pengetahuan dan pengertian kepada orang tua dari anak RM mengenai penyebab terjadinya RM.

Vaksinasi MMR secara dramatis telah menurunkan angka kejadian rubella (campak Jerman) sebagai salah satu penyebab RM. 
Amniosentesis dan contoh vili korion merupakan pemeriksaan diagnostik yang dapat menemukan sejumlah kelainan, termasuk kelainan genetik dan korda spinalis atau kelainan otak pada janin.

Setiap wanita hamil yang berumur lebih dari 35 tahun dianjurkan untuk menjalani amniosentesis dan pemeriksaan vili korion, karena memiliki resiko melahirkan bayi yang menderita sindroma Down.

USG juga dapat membantu menemukan adanya kelainan otak. Untuk mendeteksi sindroma Down dan spina bifida juga bisa dilakukan pengukuran kadar alfa-protein serum.

Diagnosis RM yang ditegakkan sebelum bayi lahir, akan memberikan pilihan aborsi atau keluarga berencana kepada orang tua.

Tindakan pencegahan lainnya yang dapat dilakukan untuk mencegah terjadinya RM:

- Genetik

Penyaringan prenatal (sebelum lahir) untuk kelainan genetik dan konsultasi genetik untuk keluarga-keluarga yang memiliki resiko dapat mengurangi angka kejadian RM yang penyebabnya adalah faktor genetik.

- Sosial

Program sosial pemerintah untuk memberantas kemiskinan dan menyelenggarakan pendidikan yang baik dapat mengurangi angka kejadian RM ringan akibat kemiskinan dan status ekonomi yang rendah.

- Keracunan

Program lingkungan untuk mengurangi timah hitam dan merkuri serta racun lainnya akan mengurangi RM akibat keracunan. Meningkatkan kesadaran masyarakat akan efek dari pemakaian alkohol dan obatobatan selama kehamilan dapat mengurangi angka kejadian RM.

- Infeksi

Pencegahan rubella kongenitalis merupakan contoh yang baik dari program yang berhasil untuk mencegah salah satu bentuk RM.

Kewaspadaan yang konstan (misalnya yang berhubungan dengan kucing, toksoplasmosis dan kehamilan), membantu mengurangi RM akibat toksoplasmosis.

\section{b. Autis}

\section{- Definisi Autis}

Autisme bukanlah penyakit menular, namun suatu gangguan perkembangan yang luas yang ada pada anak. Seorang ahli mengatakan autisme adalah dasar dari manusia yang berkepribadian ganda (Sizhophren). Autis pada anak berbeda-beda tarafnya dari yang ringan sampai yang berat. Autis dapat terjadi pada siapa saja tanpa membedakan perbedaan status sosial maupun ekonomi. Dengan perbandingan 4:1 pada anak laki-laki. IQ pada anak autis bisa dari yang rendah sampai IQ yang tinggi (Gunawan, 2001). 


\section{- Gejala-gejala pada anak Autis}

Gejala pada anak autis sudah tampak sebelum anak berumur 3 tahun, yaitu antara lain dengan tidak adanya kontak mata, dan tidak menunjukkan responsif terhadap lingkungan. Jika kemudian tidak diadakan terapi, maka setelah usia 3 tahun perkembangan anak terhenti/mundur, seperti tidak mengenal suara orang tuanya dan tidak mengenal namanya.

\section{- Jenis-jenis Autis}

Jenis-jenis autis dibedakan menjadi dua:

1. Autisme disertai hiperaktif (aktif)

2. Autisme tidak disertai hiperaktif (pasif)

\section{- Penyebab Autis}

Penyebab utama belum diketahui dengan pasti. Autisme diduga disebabkan oleh gangguan neurobiologis pada susunan syaraf pusat:

- Faktor genetik

- Gangguan pertumbuhan sel otak pada janin

- Gangguan pencernaan

- Keracunan logam berat

- Gangguan Auto - Imun

\section{- Cara Penanggulangan Autis}

Berdasarkan adanya gangguan pada otak, Autisme tidak dapat sembuh total tetapi gejalanya dapat dikurangi, perilaku dapat diubah ke arah positif dengan berbagai terapi.

1. Mengamati perilaku anak secara mendalam

2. Mengetahui riwayat perkembangannya

3. Pemeriksaan medis (kerja sama dengan dokter, psikolog)

4. Melakukan terapi wicara dan perilaku

\section{c. Conduct Disorder}

Conduct disorder adalah satu kelainan perilaku yang mana anak sulit membedakan benar salah, baik buruk; sehingga anak merasa tidak bersalah walaupun dia sudah berbuat kesalahan. Dampaknya akan sangat buruk bagi perkembangan sosial anak tersebut maupun perkembangan lainnya. Demikian pula perilaku agresif seorang anak, harus ada suatu langkah yang dapat memperbaikinya.

\section{- Simpton conduct disorder}

Menurut DSM (Diagnostic of Statistical Manual of Mental Disorder), Conduct disorder merupakan suatu pola perilaku yang terus berulang di mana hak dasar orang lain atau norma atau aturan dalam masyarakat dilanggar, yang dimanifestasikan dengan keberadaan tiga ( atau lebih ) kriteria berikut dalam 12 bulan terakhir, dan sedikitnya satu kriteria harus ada dalam 6 bulan terakhir (Jurnal, 2003). 
- Agresi terhadap orang-orang dan binatang:

1. Sering marah-marah,menakuti orang lain

2. Sering memulai perkelahian, fisik

3. Mengguanakan senjata yang dapat menyebabkan ancaman fisik serius (tongkat pemukul, batu, pisau, dan lain lain)

4. Melakukan kekejaman fisik kepada binatang

5. Melakukan kekejaman fisik kepada orang lain.

- Perusakan Properti atau barang-barang:

1. Melempar-lempar barang yang ada dihadapannya ketika marah

2. Melempar barang-barang untuk melukai seseorang atau binatang

\section{- Jenis-jenis conduct disorder}

Dibawah ini merupakan beberapa kategori conduct disorder menurut The ICD-10 Classification of Mental and Behavioral Disorders yang dikeluarkan oleh World Health Organization (WHO, 1992).

1. Conduct disorder yang dibatasi dalam konteks keluarga: merupakan conduct disorder yang meliputi perilaku abnormal sepenuhnya, atau hampir sepenuhnya, dibatasi dengan rumah dan atau interaksi dengan keluarga.

2. Conduct disorder yang tidak terisolasi: merupakan conduct disorder yang ditandai dengan kombinasi perilaku disosial dan agresif yang berulang (tidak hanya perilaku melawan, menyimpang, atau mengganggu), dengan abnormalitas yang dapat menembus secara signifikan dalam hubungan individualnya dengan anak-anak yang lain.

3. Conduct disorder yang terisolasi: merupakan conduct disorder yang meliputi perilaku sosial dan agresif yang berulang (tidak hanya perilaku melawan, menyimpang, atau mengganggu), yang terjadi pada individu yang terintegrasi dengan baik ke dalam peer group-nya.

Treatment bagi anak dengan conduct disorder:

- Trannning bagi orang tua untuk dapat mengenali perilaku anak atau remaja yang mengalami conduct disorder

- Terapi keluarga

- Tranning problem solving skills untuk anak dan remaja tersebut

- Community base service yang difokuskan pada anak-anak dalam keluarga atau lingkungan disekitarnya

Terapi yang mungkin dilakukan untuk anak penyandang conduct disorder adalah sebagai berikut:

- Pendekatan Cognitive-Behavioral

Tujuan dari Cognitive-Behavioral adalah untuk meningkatkan kemampuan anak dalam Problem solving skills, Communications skills, Impuls control, dan Anger management skills. 
- Family theraphy

Family theraphy adalah terapi yang mengfokuskan pada perubahan system keluarga seperti meningkatkan communications skills dan interaksi dalam keluarga.

- Peer group theraphy

Peer group theraphy adalah terapi yang difokuskan peningkatan social skills dan interpersonal skills

- Medication

Meskipun bukan merupakan threatment yang efektif, namun obat dapat digunakan untuk simpton atau gangguan yang responsive terhadap obatobatan.

\section{d. Attentation Deficit Hyperactive Disorders (ADHD)}

Adalah kependekan dari Attentation Deficit Hyperactive Disorders yang merupakan istilah yang paling sering digunakan untuk menyatakan suatu keadaan yang memiliki karakterisrik utama ketidakmampuan memusatkan perhatian,impulsivitas, dan hiperaktivitas yang tidak sesuai dengan perkembangan anak (Jurnal, 2003).

\section{- Penyebab ADHD}

Ditimbulkan Karena faktor lingkungan sosial atau karena metode pengasuhan anak, penyebab yang paling subtansi dan paling diyakini adalah faktor neurologi dan faktor genetis. Semua faktor memberikan dampak peningkatan terhadap gangguan.

\section{- Pengobatan / terapi ADHD}

- Terapi Medikasi

Terapi medikasi atau famakologi adalah penanganan dengan mengguanakan obat-obatan.

- Terapi Nutrisi

Terapi nutrisi adalah terapi yang mengacu pada keseimbanganan makana. Seperti keseimbangan karbohidrat, penanganan gangguan pencernaan.

- Terapi Biomedis

Terapi biomedis dilakukan dengan pemberian suplemen nutrisi, defisiensi mineral, essential fatty Acids, gangguan metabolism asam amino dan toksisitas ligam berat.

- Terapi modifikasi prilaku

Terapi modifikasi perilaku harus melalui pendekatan perilaku secara langsung, dengan lebih mengfokuskan pada perubahan spesifik. Modifikasi perilaku merupakan pola penanganan yang paling efektif dengan positif dan dapat menghindarkan anak dari perasaan frustasi, marah, dan berkecil hati menjadi perasaan yang penuh percaya diri. 


\section{PERANCANGAN DAN IMPLEMENTASI}

\subsection{Perancangan Basis Pengetahuan}

Dalam perancangan basis pengetahuan ini digunakan kaidah produksi sebagai sarana untuk representasi pengetahuan. Kaidah produksi dituliskan dalam bentuk pernyataan JIKA [premis] MAKA [konklusi]. Pada perancangan basis pengetahuan sistem pakar ini premis adalah gejala-gejala yang terlihat pada anak dan konklusi adalah jenis gangguan perkembangan yang diderita anak, sehingga bentuk pernyataannya adalah JIKA [gejala] MAKA [gangguan].

Bagian premis dalam aturan produksi dapat memiliki lebih dari satu proposisi yaitu berarti pada sistem pakar ini dalam satu kaidah dapat memiliki lebih dari satu gejala. Gejala-gejala tersebut dihubungkan dengan menggunakan operator logika DAN. Bentuk pernyatannya adalah:

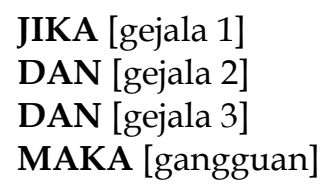

Adapun contoh kaidah Sistem Pakar Menentukan Gangguan Perkembangan pada Anak adalah sebagai berikut:

JIKA Anak Sulit Berbicara

DAN Tes IQ Dibawah !9

DAN Koordinasi Otot Tidak Sempurna

MAKA Gangguan Retardasi Mental Berat

Berdasarkan contoh kaidah pengetahuan diatas maka kaidah tersebut dapat disimpan dalam bentuk sebuah tabel sehingga dapat lebih mudah untuk di mengerti. Dimana pada tabel tersebut terdapat kolom jenis gangguan yang menjelaskan tentang definisi,penyebab, dan pengobatan.

\subsection{Perancangan Mesin Inferensi}

Metode penalaran yang digunakan dalam sistem adalah penalaran pelacakan maju (Forward Chaining) yaitu dimulai dari sekumpulan fakta-fakta tentang suatu gejala yang diberikan oleh pengguna sebagai masukan sistem, untuk kemudian dilakukan pelacakan sampai tujuan akhir berupa diagnosis kemungkinan jenis gangguan perkembangan yang diderita dan penjelasan tentang jenis gangguan yang diderita serta cara pengobatannya. Dalam proses penarikan kesimpulan dapat dilihat pada Gambar 8.

\subsection{Implementasi Perangkat Lunak}

Sistem Pakar Menentukan Gangguan Perkembangan pada Anak ini, dalam implementasinya dibatasi pada tambah, update dan delete data pasien, pakar, gejala, gangguan, pengetahuan, dan berita. Implementasinya terdiri dari beberapa halaman yang memiliki fungsi sendiri-sendiri. Halaman-halaman tersebut akan 
tampil secara berurutan sesuai dengan urutan yang telah terprogram, setelah pengguna melakukan proses tertentu.

Halaman layanan berisi tentang informasi dari sistem pakar yang dibuat. Pada halaman ini menggambarkan tentang kegunaan dari sistem ini. Tampilan dari halaman layanan dapat dilihat pada Gambar 9.

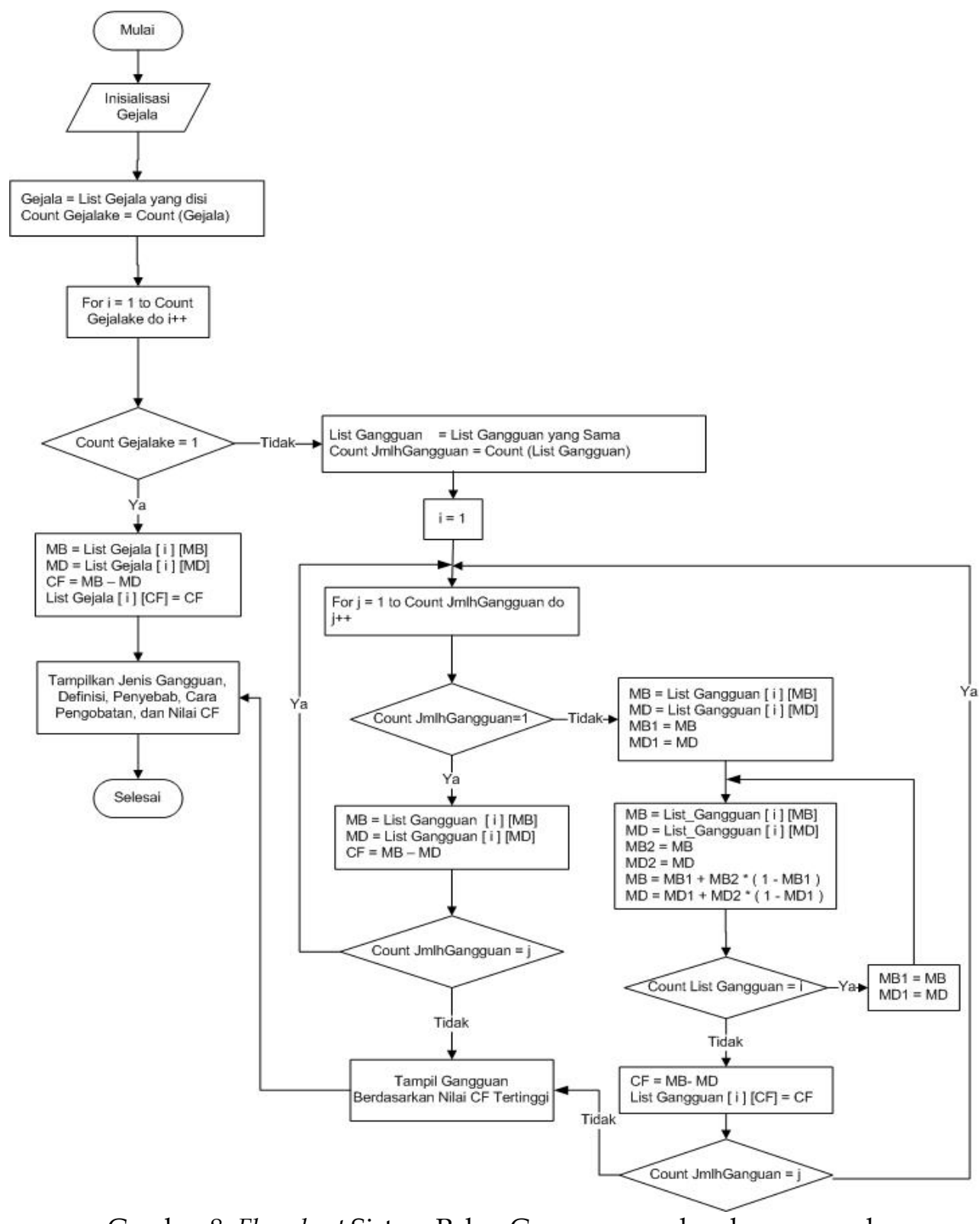

Gambar 8. Flowchart Sistem Pakar Gangguan perkembangan anak 


\section{PEMBAHASAN}

\subsection{Pengujian Kebenaran Sistem}

Pengujian kebenaran sistem dilakukan untuk mengetahui kesamaan hasil akhir atau output yang berupa kemungkinan jenis gangguan yang dihasilkan oleh sistem, dengan yang dihasilkan oleh perhitungan secara manual. Untuk mengetahui hasil output dari sistem harus melakukan konsultasi terlebih dahulu yang kemudian memasukkan gejala-gejala yang dirasakan oleh pasien kemudian setelah selesai melakukan konsultasi maka akan muncul halaman hasil konsultasi yang akan menampilkan kemungkinan jenis gangguan perkembangan yang dialami oleh pasien. Pengujian kebenaran sistem dilakukan dengan melakukan beberapa ujicoba diantaranya sebagai berikut:

1. Dengan satu gejala satu jenis gangguan

2. Dengan satu gejala beberapa jenis gangguan

3. Dengan beberapa gejala satu jenis gangguan

4. Dengan beberapa gejala beberapa gangguan berikutnya.

Penjelasan hasil dari beberapa ujicoba tesebut akan dijelaskan pada sub bab

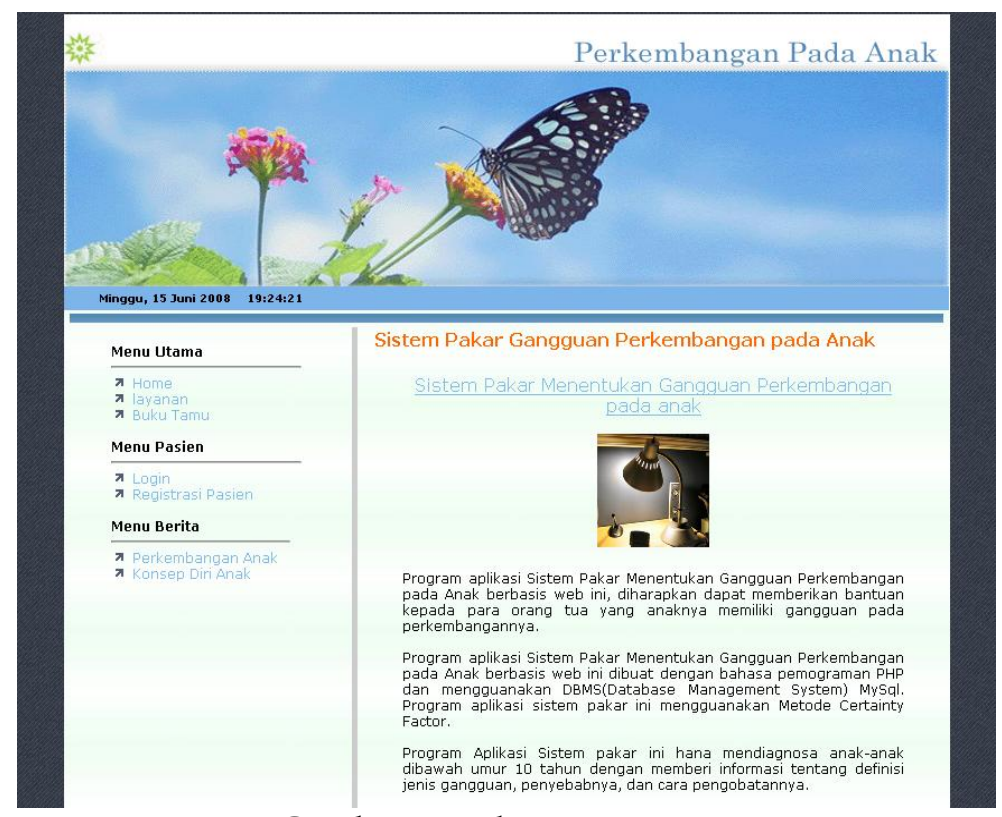

Gambar 9. Halaman Layanan

\subsubsection{Pengujian Satu Gejala Satu jenis gangguan}

Pada pengujian satu gejala untuk satu jenis gangguan ini, percobaan akan menggunakan gejala kontak mata, ekspresi muka, dan gerak-gerik tubuh kurang hidup dengan kemungkinan mengalami jenis gangguan perkembangan Autisme Aktif dengan nilai $\mathrm{MB}=0.9$ dan $\mathrm{MD}=0.1$. 
Berdasarkan data diatas, apabila menggunakan perhitungan manual maka hasil perhitungannya adalah sebagai berikut:

CF [Autisme Aktif, Kontak mata dan ekspresi muka kurang hidup] $=0.9-0.1=0.8$

Berdasarkan perhitungan manual tersebut nilai CF (Faktor Kepastian) yang dihasilkan dapat ditarik kesimpulan bahwa kemungkinan pasien tersebut mengalami gangguan perkembangan Autisme Aktif dengan nilai $\mathrm{CF}=0.8$

Berdasarkan perhitungan dengan menggunakan sistem menghasilkan kemungkinan pasien mengalami jenis gangguan perkembangan yaitu Autisme Aktif dan dapat melihat secara detail definisi, penyebab, dan pengobatannya. Form detail gengguan dapat dilihat pada Gambar 10.

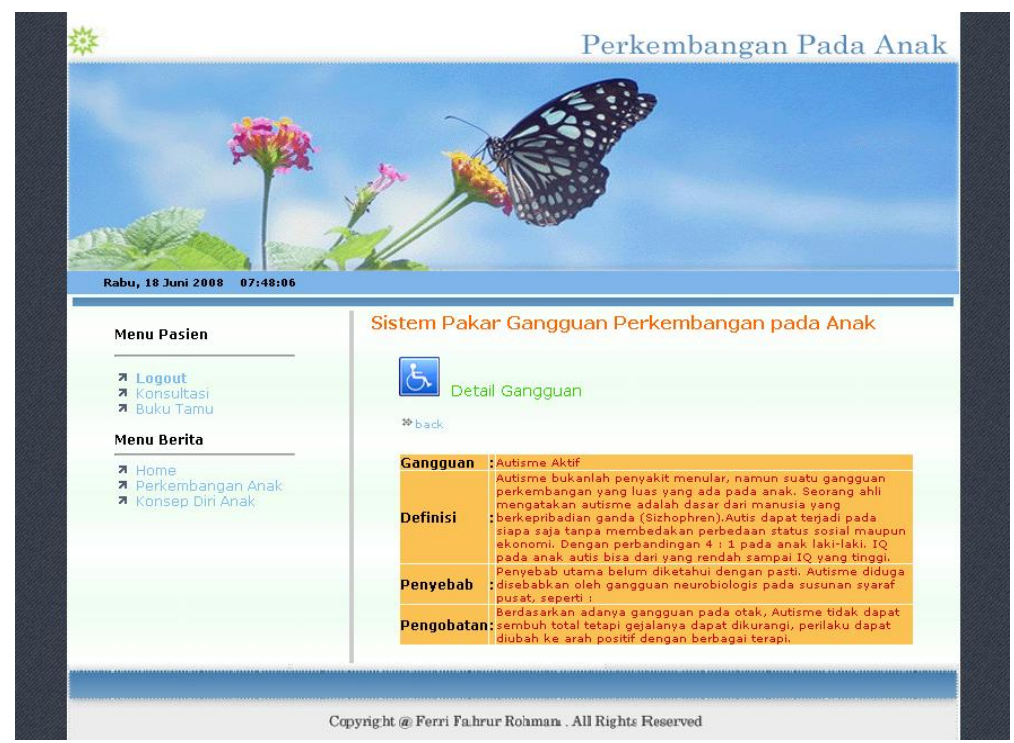

Gambar 10. Hasil konsultasi detail Gejala Satu jenis gangguan

Berdasarkan hasil percobaan tersebut dengan melakukan perhitungan baik manual maupun sistem dapat dibandingkan bahwa hasil akhir atau output dari sistem yang berupa kemungkinan gangguan sama dengan hasil yang dilakukan oleh perhitungan manual dengan nilai CF sebesar 0.8 dengan kemungkinan jenis gangguan Autisme Aktif.

\subsubsection{Pengujian Satu Gejala Beberapa Gangguan}

Pada pengujian satu gejala beberapa gangguan ini, percobaan akan menggunakan gejala Kesadaran anak untuk bersosialisasi kurang dengan kemungkinan akan mengalami beberapa gangguan diantaranya adalah: Mengalami Gangguan: Retardasi Mental Ringan dengan nilai MB $=0.5$ dan $\mathrm{MD}=$ 0.05 , Retardasi Mental Moderat dengan nilai $\mathrm{MB}=0.7$ dan $\mathrm{MD}=0.1$, Autisme Aktif dengan nilai $\mathrm{MB}=0.89$ dan $\mathrm{MD}=0.1$, dan Disfraxsia dengan nilai $\mathrm{MB}=0.4$ dan $\mathrm{MD}=0.1$. 
Berdasarkan data diatas, apabila menggunakan perhitungan manual maka hasil perhitungannya adalah sebagai berikut:

CF [Retardasi Mental Ringan, Kesadaran anak untuk bersosialisasi kurang] $=0.5-0.05=0.45$

CF [Retardasi Mental Moderat, Kesadaran anak untuk bersosialisasi kurang] $=0.7-0.1=0.6$

CF [Autisme Aktif, Kesadaran anak untuk bersosialisasi kurang] $=0.89-0.1=0.79$

$\mathrm{CF}$ [Disfraxsia, Kesadaran anak untuk bersosialisasi kurang] $=0.4-0.1=0.3$

Berdasarkan perhitungan manual tersebut berdasarkan nilai CF (Faktor Kepastian) yang tertinggi dapat ditarik kesimpulan bahwa kemungkinan pasien tersebut mengalami gangguan perkembangan Autisme Aktif dengan nilai $\mathrm{CF}=$ 0.79

Berdasarkan perhitungan dengan menggunakan sistem menghasilkan kemungkinan pasien mengalami jenis gangguan perkembangan yaitu Autisme Aktif dan dapat melihat secara detail definisi, penyebab, dan pengobatannya. Form detail gangguan dapat dilihat pada Gambar 11.

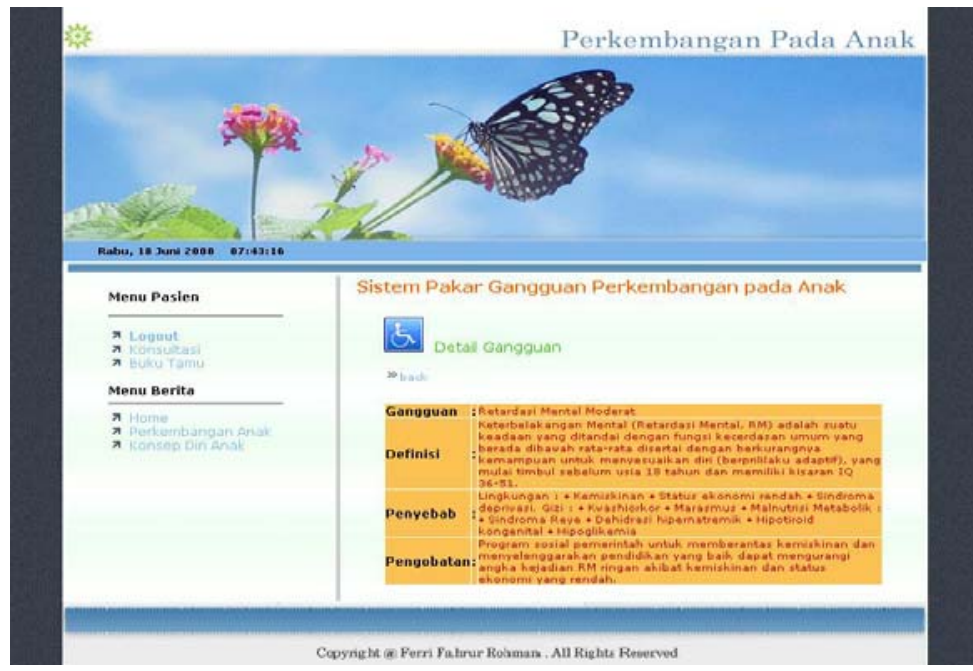

Gambar 11. Hasil konsultasi detail Salah Satu jenis gangguan

Berdasarkan perhitungan dengan menggunakan sistem menghasilkan kemungkinan beberapa jenis gangguan yaitu Retardasi Mental Ringan, Retardasi Mental Moderat, Autisme Aktif, dan Disfraxsia.

Berdasarkan hasil percobaan tersebut dengan melakukan perhitungan baik manual maupun sistem dapat dibandingkan bahwa hasil akhir atau output dari sistem yang berupa kemungkinan jenis gangguan sama dengan hasil yang dilakukan oleh perhitungan manual dengan nilai CF terbesar yaitu sebesar 0.79 dengan kemungkinan jenis gangguan Autisme Aktif.

\subsubsection{Pengujian Beberapa Gejala Satu Gangguan}

Pada pengujian beberapa gejala satu gangguan ini, percobaan akan menggunakan beberapa gejala yaitu: Anak kesulitan menjaga konsentrasi dlm 
aktivitasnya dengan nilai $\mathrm{MB}=0.85$ dan $\mathrm{MD}=0.10$, Sering gagal dalam memberi perhatian secara jelas dengan nilai $\mathrm{MB}=0.70$ dan $\mathrm{MD}=0.35$ dan Sering membuat kesalahan yang tidak terkontrol dengan nilai $\mathrm{MB}=0.89$ dan $\mathrm{MD}=0.10$. Ketiga gejala tersebut kemungkinan akan mengalami gangguan Pemusatan Perhatian dan Hiperaktif.

Berdasarkan data diatas, apabila menggunakan perhitungan manual maka hasil perhitungannya adalah sebagai berikut:

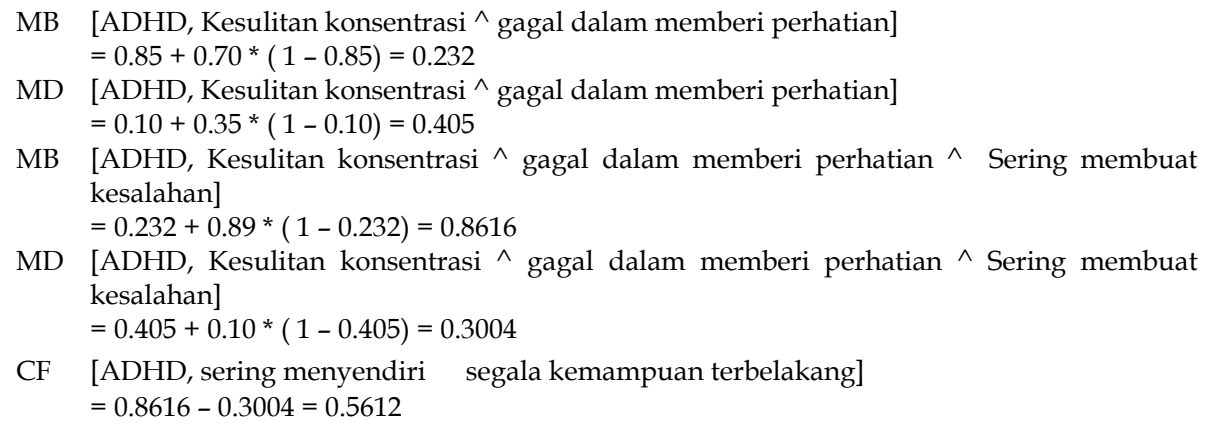

MB [ADHD, Kesulitan konsentrasi $\wedge$ gagal dalam memberi perhatian $\wedge$ Sering membuat kesalahan]

MD [ADHD, Kesulitan konsentrasi $\wedge$ gagal dalam memberi perhatian $\wedge$ Sering membuat kesalahan]

CF [ADHD, sering menyendiri segala kemampuan terbelakang] $=0.8616-0.3004=0.5612$

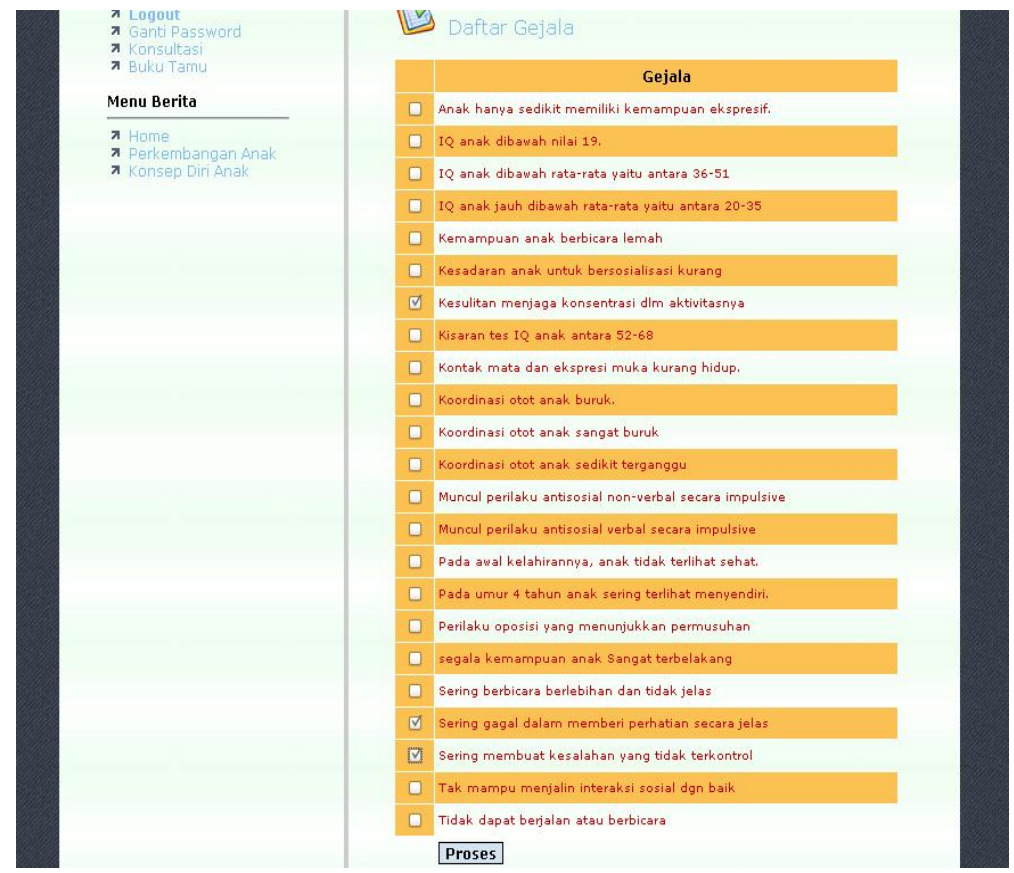

Gambar 12. Konsultasi Beberapa Gejala Satu Gangguan

Berdasarkan perhitungan manual tersebut berdasarkan nilai CF (Faktor Kepastian) yang dihasilkan dapat ditarik kesimpulan bahwa kemungkinan pasien tersebut mengalami gangguan Pemusatan Perhatian dan Hiperaktif dengan nilai $\mathrm{CF}=0.5612$. 
Kemudian dengan menggunakan perhitungan oleh sistem, dengan memasukkan gejala-gejala yang dirasakan tersebut ke dalam sistem, seperti pada Gambar 12.

Setelah selesai melakukan konsultasi tersebut kemudian klik tombol "Proses" maka akan tampil form hasil konsultasi beserta kemungkinan gangguan yang diderita oleh pasien. Form hasil konsultasi dapat dilihat pada Gambar 13.

Berdasarkan hasil percobaan tersebut dengan melakukan perhitungan baik manual maupun sistem dapat dibandingkan bahwa hasil akhir atau output dari sistem yang berupa kemungkinan gangguan sama dengan hasil yang dilakukan oleh perhitungan manual dengan nilai $\mathrm{CF}$ sebesar 0.56 dengan kemungkinan gangguan Pemusatan Perhatian dan Hiperaktif.

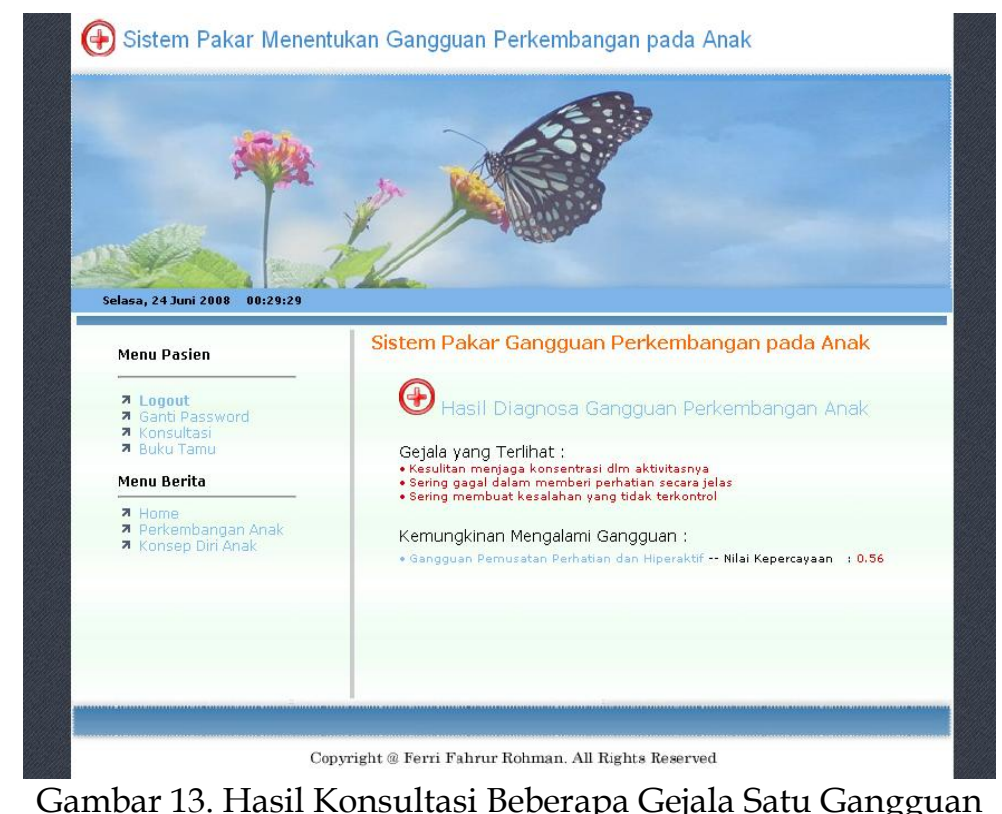

\subsubsection{Pengujian Beberapa Gejala beberapa Gangguan}

Pada pengujian beberapa gejala beberapa gangguan ini, percobaan akan menggunakan beberapa gejala yaitu: Anak hanya sedikit memiliki kemampuan ekspresif dengan nilai $\mathrm{MB}=0.50$ dan $\mathrm{MD}=0.10$, Kesulitan menjaga konsentrasi dlm aktivitasnya dengan nilai $\mathrm{MB}=0.85$ dan $\mathrm{MD}=0.10$. Kedua gejala tersebut kemungkinan akan terkena gangguan perkembangan yaitu Disfraxia dan Gangguan Pemusatan Perhatian\&Hiperaktif(ADHD).

Berdasarkan data diatas, apabila menggunakan perhitungan manual maka hasil perhitungannya adalah sebagai berikut:

CF [Disfraxia, Anak hanya sedikit memiliki kemampuan ekspresif]

$=0.50-0.10=0.40$

CF [ADHD, Kesulitan menjaga konsentrasi dlm aktivitasnya]

$=0.85-0.10=0.75$ 
Berdasarkan perhitungan manual tersebut berdasarkan nilai CF (Faktor Kepastian) yang dihasilkan dapat ditarik kesimpulan bahwa kemungkinan pasien tersebut mengalami Gangguan Pemusatan Perhatian \& Hiperaktif(ADHD) dengan nilai $\mathrm{CF}=0.75$ dan dengan kemungkinan mengalami gangguan Disfraxia dengan nilai $\mathrm{CF}=0.40$.

Berdasarkan perhitungan dengan menggunakan sistem menghasilkan kemungkinan gangguan yaitu Disfraxia

Berdasarkan hasil percobaan tersebut dengan melakukan perhitungan baik manual maupun sistem dapat dibandingkan bahwa hasil akhir atau output dari sistem yang berupa kemungkinan gangguan, sama dengan hasil yang dilakukan oleh perhitungan manual dengan kemungkinan mengalami Gangguan Pemusatan Perhatian \& Hiperaktif(ADHD) dengan nilai $\mathrm{CF}=0.75$ dengan kemungkinan mengalami gangguan Disfraxia dengan nilai $\mathrm{CF}=0.40$.

\section{SIMPULAN}

Aplikasi sistem pakar yang dibuat ini mampu menganalisis jenis gangguan perkembangan yang dialamai pasien berdasarkan gejala-gejala yang dimasukkan oleh user. Aplikasi mampu menyimpan representasi pengetahuan pakar berdasarkan nilai kebenaran MB dan nilai ketidakbenaran MD. Aplikasi sistem pakar ini sudah dapat menjelaskan definisi jenis gangguan perkembangan, penyebab, dan pengobatannya.

Kekurangan dari aplikasi ini adalah belum adanya pengelompokan gejalagejala sejenis yang hanya boleh dipilih satu dari kelompok gejala tersebut. Akibatnya, jika user kurang teliti dalam memilih gejala, maka sistem akan memberikan kesimpulan yang kurang benar.

\section{PUSTAKA}

Berndt, T. J. (1992). Child Development. New York: Brace Jovenovich College Publisher.

Dewi, F., Ir. (1999). Anak dan Lingkungan Sosialnya. Jogjakarta: Jurnal Ilmiah Psikologi.

Gunawan, J., Dra. (2001). Autis. Blog Julianita Gunawan.

Jurnal. (2003) Jurnal Ilmiah Psikilogi UGM. Jogjakarta: Jurnal Psikologi.

Kusumadewi, S. (2003). Artificial Intelligence (Teknik dan Aplikasinya). Yogyakarta: Graha Ilmu.

Le Fanu, J. (2002). Deteksi Dini Gangguan Perkembangan pada Anak. London: James Le Fanu.

Maslim, R. (2002). Diagnosis Gangguan Jiwa Rujukan Ringkas dari PPDGJ. Jakarta: Rusdi Maslim.

Maharani, V. T. (2007). Keterbelakangan Mental. Blog Tanaya Maharani.

Turban, E. (1995). Decision Support and Expert System; Management Support System. Newyork: Prentice-Hall.

WHO. (1992). The ICD-10 Classification of Mental and Behavioral Disorders. http://www.mentalhealth.com. 